\title{
Калькирование как способ номинации в русском языке на переломе XX и XXI столетий
}

\author{
ЕВА ФОРИАН \\ FóRIÁN Éva, Debreceni Egyetem, Szlavisztikai Intézet, Debrecen, Pf. 53, H-4010 \\ E-mail:eforian@wp.pl
}

\begin{abstract}
The author's purpose is to draw attention to this implicit way of borrowings from English into Russian. After a brief introduction to modern loan-translation research (the notion of substitution and its verification), she proposes to explain this kind of lexical process with a great number of examples arranged according to J. Obara's typology (first published in 1989).

Keywords: contemporary Russian, contemporary English, lexical borrowing, loanword, loan meaning, partial substitution
\end{abstract}

Кальки менее заметны, чем заимствования.

Это, так сказать, тайный переодетый враг, а не явный грабитель, который ломится в дом. ${ }^{1}$

\section{0. Введение}

Основные процессы формирования лексики русского литературного языка конца XX начала XXI в. теснейшим образом связаны с общественно-политическими и экономическими изменениями в нынешней России. Стремительные общественные и экономические перемены, социальные потрясения в конце XX в. вызвали настоящий лексический взрыв в языках СреднеВосточной Европы, в том числе и в русском. Развитие в настоящее время экономических, политических и культурных контактов между Россией и Западом отражается в одном из наиболее энергичных и социально значимых процессов, происходящих в современной русской речи - в процессе активизации ${ }^{2}$ заимствования и употребления иноязычной лексики для номинации новых явлений, а также замены существующих наименований. При относительной этимологической однородности новых заимствований - их подавляющее большинство составляют английские заимствования, наблюдается разнообразность и интенсивность иноязычного влияния на русскую лексику. Оно требует основательного и детального исследования, учитывающего как относительно легко обнаруживаемые лексические заимствования, так и разные формы скрытого воздействия других языков на русский. В исследуемый период значителен удельный вес слов, пришедших из иноязычного источника почти незаметно, путем калькирования.

\footnotetext{
1 Земская 2004, 421.

2 Л. П. Крысин подчеркивает именно активизацию этих слов, а не просто появление новых заимствований (ср. 2000 , 142).
} 
Состояние современного русского языка на рубеже XX и XXI столетий, изменения, которые в нем активно совершаются, изучаются и освещаются в последнее время целым рядом лингвистов в России и за рубежом. Несмотря на значимость и актуальность задачи определения значения и возможностей обогащения русской лексики путем калькирования, данная тема недостаточно полно освещена в специальной литературе. Два, изданных в новом тысячелетии, относительно комплексных, но недостаточно освещающих теоретические проблемы калькирования как способа пополнения русского языка - в период царствования Петра Великого: Кальки в русском языке послепетровского периода. Опыт словаря Н. С. Араповой (2000); и англоязычная монография о семантических и фразеологических кальках, как результатах французского влияния на русскую литературу XVIII века: The Influence of French on Eighteenth-Century Literary Russian. Semantic and Phraseological Calques, автором которой является May Smith (2006). ${ }^{3}$

Настоящая работа ставит своей целью обратить внимание исследователей на богатство анализируемого языкового явления, на его современные потенциальные примеры, не разрабатывая, из-за ограниченного объема труда, комплекс теоретических вопросов. ${ }^{4}$ Работа состоит из двух основных частей: в первой части определяются главные термины (кальки и калькирование), а во второй анализируются образцы процессов калькирования в русском языке наших дней - по типологии Й. Обары.

В основу данной работы положены лексикографические источники, разработанные под редакцией Г. Н. Скляревской в конце XX века в Институте лингвистических исследований РАН: Толковый словарь русского языка конща ХХ века. Языковые изменения (1998) и Толковый словарь современного русского языка. Языковые изменения конияа ХХ века (2001).

\section{1. Калькирование}

Калькирование является одним из средств обогащения словарного состава языка наряду со словообразованием по исконным образцам и обыкновенными (фонетическими) заимствованиями. Новообразования всех этих типов свидетельствуют о событиях истории культуры, об идейных течениях, об истории языка и самих реалий. Заимствование является одновременно выражением и результатом культурной общности нескольких народов и, в свою очередь, ведет к дальнейшему сближению языков, причем не только к сближению словаря, но и структуры.

В данной работе, опираясь на излагаемую польским языковедом Й. Обара (Obara 1989, 60 62) универсальную типологию калек, основанную на взглядах разных лингвистов, пионеров

\footnotetext{
3 Иноязычные заимствования, в том числе и лексико-фразеологические кальки в русском литературном языке 70-90$\mathrm{x}$ гг. XX века обследует в своей диссертации на соискание ученой степени кандидата филологических наук - также В. М. Феоклистова (по Крысин 2002).

4 Рассмотрение калькирования как комплексной проблемы языковых контактов осуществляется в изготовляемой автором данной работы докторской диссертации.
} 
исследования вопроса, мы исходим из следующего подразделения калек на основные типы и группы:

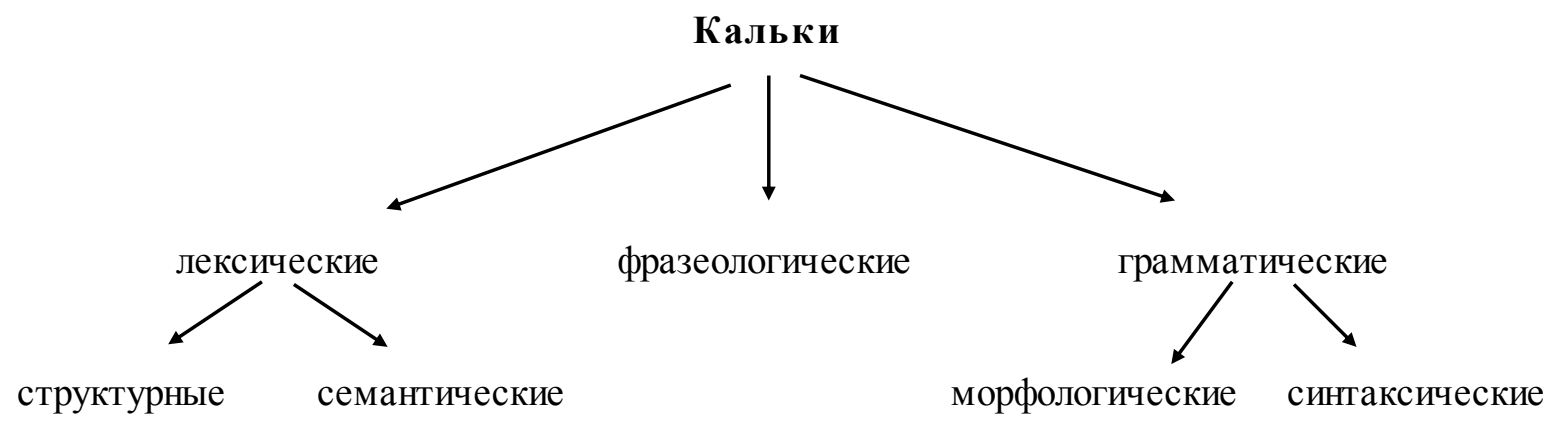

В центре нашего внимания стоят исключительно лексические и фразеологические кальки. Итак, в дальнейшем, все замечания насчет калек и калькирования касаются только лишь неграмматических типов и процессов калькирования.

Подытоживая суть процесса, описанного многими авторами и получившего в русской лингвистической терминологии название «калькирование», мы предлагаем следующие дефиниции:

Калькирование, это

- явление лексической интерференции,

- один из типов заимствования,

- осуществленное двуязычными субъектами,

- в основе которого лежит иноязычный прототип,

- воспроизведением которого в принимающем языке является калька.

Кальки

- зависят от иноязычного прототипа

- семантически

- и формально;

- создаются

- обычно для обозначения новых понятий, возникших и получивших наименования в языке-доноре;

- путем перевода

- значимых частей лексических единищ

- по образцу соответствующих слов иностранного языка и

- по законам словообразования принимающего языка, или

- путем придания 
- исконным словам языка-реципиента

- отсутствовавшего у них ранее переносного значения

- по образцу некоторых слов иностранного языка.

\section{2. Установление факта калькирования}

Одинаковость структуры и совпадение в значениях (а следовательно, одинаковые по строению и значению слова) могут возникнуть в разных языках и самостоятельно, независимо друг от друга - в результате внутриязыковой мотивированности, т.е. без воздействия иноязычной модели, просто по подобному видению объективного мира. Для отнесения того или иного слова к калькам необходимо иметь вполне определенные данные, подтверждающие это. Одного структурного или семантического совпадения исконных слов с иноязычными для этого совершенно недостаточно. Собственно лингвистическими методами могут быть выявлены лишь случаи «подозрительного» (ср. Зализняк 2001, 22) сходства, если в кальках осуществятся какие-либо нехарактерные, несвойственные данному языку черты - либо в формальной, либо в содержательной стороне слова, словосочетания. ${ }^{5}$ Если в ряде случаев непосредственное языковое чутье подсказывает нам, что мы имеем дело с кальками, то в других случаях это представляется не так очевидным. Бывает и так, что направление калькирования не очевидно, хотя сам факт заимствования производного значения представляется практически бесспорным.

Установление факта калькирования требует стойких лингвистических знаний, между прочим, в области этимологии, истории, синхронического и диахронического словообразования контактирующих языков, а также разносторонних сведений о внеязыковой действительности.

Само признание некоего языкового элемента (значения) заимствованием предполагает существование его прототипа в иной языковой системе и осознание связи между данными единицами со стороны носителей принимающего языка. Языковеды согласны в том, что в качестве критерия для выделения калек должны быть использованы языковые факты: в первую очередь - семантика слова. Следующим критерием может и должен быть структурный критерий, так называемая внутренняя форма слова. Хорошие знания принципов словообразования, форм сочетаемости двух корней в одном слове или форм соединения корней и аффиксов - как в синхроническом, так и диахроническом отношении - являются предпосылками установления факта калькирования.

5 Так, среди многочисленных русских слов церковнославянского происхождения, возникших путем калькирования греческих и латинских образцов, есть группа глаголов, которые несут на себе отпечаток своего «искусственного» происхождения. Они выдают свое происхождение тем, что они, вопреки законам русского языка, относятся к несовершенному виду (они содержат приставку и не содержат показателя имперфективации, а все такие глаголы в русском языке - совершенного вида, ср. поддержать, увидеть, постоять и т.п.). Это, например, содержать, предвидеть, предстоять, зависеть, принадлежать и т.п. Аналогичным образом выдает свою «нерусскость» глагол несовершенного вида выглядеть - калька с нем. aussehen; этот глагол появился в 1830-е годы и вплоть до начала XX в. еще осуждался пуристами как противоречащий русской грамматике. 
Установление факта калькирования требует кроме филологических методов анализа также экстралингвистических факторов. Как вспомогательное средство можно и надо использовать историю культуры: окружение, в котором возникло понятие и к нему название, или принадлежность его к определенному духовному направлению, на которое влияла иноязычная культура. Время возникновения слова-кальки, а также первая ее фиксация в (не обязательно лексикографических) изданиях, написанных в языке-реципиенте играют тоже немаловажную роль при установлении факта калькирования. (При всем том общеизвестен факт, что отсутствие слова или значения в словаре не является доказательством о его отсутствии в лексическом составе данного языка. Новые слова и значения могут долгое время ждать, чтобы войти в литературный язык.)

Для того, чтобы упорядочить все лексические факты, предстоит выполнить чрезвычайно трудоемкую работу. Реализация задач требует применения, главным образом, следующих методов:

1. Источниковедческое рассмотрение словарных статей. Лексикографические определения одноязычных словарей являются по сути дела первым важным приближением к решению поставленной задачи. Не останавливаясь на вопросе о том, насколько удачно выделены здесь значения (и даны их толкования), попытаемся определить общий характер существующих между ними связей.

2. Семантический разбор прототипа и кальки, при чем обязательно учитывать факт: всегда заимствуется конкретный лексико-семантический вариант, конкретное значение, а не лексема в целом как комплекс значений. ${ }^{6}$

3. Структурный анализ лексических структурных и фразеологических единиц: при словах-кальках словообразовательный, а при словосочетаний-калек также синтаксический анализ прототипа и кальки.

Хотя подавляющее большинство калек все же поддается идентификации - как по чисто лингвистическим, так и по экстралингвистическим основаниям, однако мы должны нередко удовлетворяться выдвижением какой-то возможности, ведь не всегда имеется потенциал категоричного решения (cp. Kiss 1976, 4). Чтобы найти ответ на вопрос, является ли данное слово (словосочетание) действительно нефонетическим заимствованием или результатом внутренних словообразовательных или семантических процессов, мы должны найти ответы на следующие вопросы:

6 Проследим это на известном примере слова трогать (см. Шанский 1959, 201 и Фомина 1983, 146). Основой для заимствования русским глаголом трогать переносного значения «вызывать в ком-нибудь сочувствие, приводить

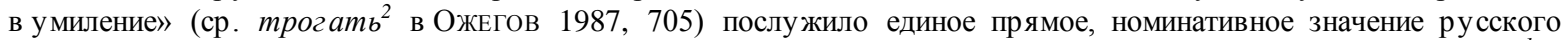
(mрогать) и французского (toucher) глаголов - «прикасаться к кому/чему-нибудь, задевать» (ср. mpoz amb $^{I}$ в ОЖЕГов 1987, 704). Слово трогать в переносном значении, а также образованное от него прилагательное трогательный появились в русском языке на рубеже XVIII и XIX вв. - наряду со многими другими семантическими кальками, созданными в эту эпоху; например, слова влияние, вдохновение, впечатление приобрели современное значение под влиянием имеющих ту же внутреннюю форму французских слов influence, inspiration, impression. 
- Существует ли иноязычный прототип, лежащий в основе калькирования?

- Обнаруживается ли семантическое соприкосновение между прототипом и калькой?

- Имеют ли иноязычное слово и его калька одинаковую (похожую) словообразовательную структуру?

- Какой тип калькирования представляет собой данная калька?

\section{3. Структурные кальки}

Синонимами применяемого в работе Обары (Obara 1989, 76) термина «лексические структурные кальки» являются в русской терминологии «словообразовательные кальки» и «морфемные кальки». Они относятся к словам, образованным путем более или менее точного подражания словообразовательной структуре и значению иноязычных образцов, заменой иноязычных словообразовательных элементов исконными. Имея ввиду степень буквальности копирования словообразовательной структуры и значения иноязычных образцов, лексические структурные кальки делятся на две основные группы: точные и неточные кальки.

На основе вышесказанного мы можем высказать мнение, что языковой потребностью структурного калькирования является прозрачность внутренней формы, то есть морфологического строения. Однако, генетическая близость и конвергентные процессы прежде всего европейских языков так глубоки, что наличие структурного сходства между двумя словами часто не является достаточным для того, чтобы толковать его в одном языке как кальку.

В зависимости от отступлений от структурных свойств прототипа Обара $(1989,60-62)$ выделяет следующие подтипы лексических структурных калек:

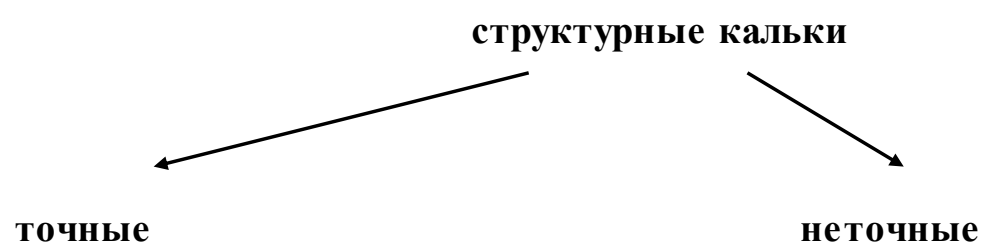

кальки - верные по структуре и значении копии прототипов иная последовательность компонентов сложных слов-прототипов

калька - однокоренное слово, ее первообраз словосложение

калька - слово, прототип - словосочетание

калька - словосложение, ее первообраз однокоренное слово

калька - словосочетание, прототип - словосложение

в кальке семантика одной из выступающих основ не тождественна семантике соотносимой основы в прототипе частичный только перевод иноязычных первообразов, размывающаяся словообразовательная прозрачность чужих слов (полукальки)

слова-замены, т.е. новообразования по образцу иноязычных слов, однако формально независимые от них 


\section{1. Точные кальки}

В узком понимании термина точной калькой является калька, верно копирующая структуру и значение иноязычного слова (телохранитель), а в широком смысле также к этому типу примыкают кальки, в которых наблюдаются некоторые количественные или качественные отступления от составляющих морфем (пятизвездочный, новояз).

\section{телохранитель}

- иноязычный прототип: анг. bodyguard;

- семантическое соприкосновение

- bodyguard 'a person or a group of people who are employed to protect' (OALD7);

○ телохранитель 'личный охранник (какого-л. высокопоставленного или достаточно состоятельного лица)' (ТСРЯ ХХ);

- структурное сходство

○ bodyguard: body 'тело, туловище' + guard 'конвоир, сторож, охранник' $(C A P C)$;

- телохранитель: тело + хранитель.

Русское слово, как и его английский прототип, является словосложением с подчинительной связью компонентов.

\section{трудоголик}

- иноязычный прототип: анг. workaholic $^{7}$;

- семантическое соприкосновение

- workaholic 'a person who works very hard and finds it difficult to stop working and do other things' (OALD7);

○ трудоголик 'очень трудолюбивый человек, у которого любовь к труду становится почти манией' (ТСРЯ XX);

- структурное сходство

○ оба слова возникло сложением двух мотивирующих основ;

○ английский прототип членится на три составные части: work + a + holic, и русское трудоголик имеет также трехчленную словообразовательную структуру: труд + о + голик;

○ первую часть слова-прототипа и слова-кальки составляет морфема с лексическим значением ' работа, занятие';

○ второй составляющей единицей в обоих словах является интерфикс: - $a$ / -o

\footnotetext{
${ }^{7}$ Английский термин возник, распространился и закрепился в общем языковом употреблении в 1960-ых годах. Его ввел в употребление американский профессор психологии, Ричард Ивенс (Richard I. Evans) - для обозначения людей, проявляющих трудоголизм, т.е. чрезмерное трудолюбие. (По другим сведениям данное слово появилось впервые в печати в 1968 г., его употребил W. E. Oates в Pastoral Psychology.)
} 
○ другой мотивирующей основой служит повторяющийся опорный компонент -holic / -голик ${ }^{8}$ с семантикой 'болезненное тяготение человека к чему-нибудь'.

К точным структурным лексическим калькам примыкают также кальки, представляющие тот же самый способ словообразования, как их первообразы, однако в них включено большее количество морфем, т.е. значимых частей - в согласии с правилами словообразования принимающего новое понятие и заимствующего одновременно его наименование языка, как в следующем случае:

\section{пятизвездочный}

- иноязычный прототип: анг. five-star;

- семантическое соприкосновение

- five-star 'having five stars in a system that measures quality. Five stars usually represents the highest quality' (OALD7);

○ пятизвездочный 'отмеченный пятью звездочками; высшего класса' (ТСРЯ $X X)$

- структурное сходство

○ five-star: five 'пять' + star 'звезда, звёздный' (CAPC);

○ пятизвездочный: $п я т(ь)+$ и + звезд + очн + ый.

Русское слово, как и его английский прототип, возникло путем сложения двух корней: первый корень сложного слова в значении 'содержащий пять единиц, состоящий из пяти единиц' (ср. пятидневный, пятирублевый, пятиугольный) составляет основа количественного числительного $n я m+b$, в качестве соединительной гласной выступает -u-, омонимичная флексии родительного падежа числительного. В качестве опорного компонента выступает мотивированное существительным (звезда) прилагательное с суффиксом -очн-. В самом конце слова-кальки выступает морфема - $\mid$ иј| - для обозначения (маркирования) морфологического значения (категории рода, числа и падежа) русского имени прилагательного. Таким способом, количество составляющих лексему-кальку морфем: пять, а в случае прототипа: всего два. Критерий структурного сходства участвующих в калькировании лексем обеспечивается общим для них словообразовательным способом и тождеством выступающих в них корней.

Хотя воспроизведение английского материала newspeak наступило через (менее) значительное формальное отступление от иноязычного прототипа, благодаря языковой

\footnotetext{
8 Повторяющийся опорный компонент -holic / -голик имеет свой источник в существительных alcohol / aлкоголь, заимствованных из арабского < al-kuhl (BSE 2000, 9). В польском языке конца XX века появились похожие типы сложений, как напр., pracoholik, pracoholiczka, pracoholizm (Smółkowa 1999, 69), internetholik, seksoholik (Waszakowa 2000, 66).

${ }^{9} \mathrm{Cp}$. alcoholic 'a person who is unable to give up the habit of drinking alcohol very frequently and in large amounts' (Cam$b A L C)$; алкоголизм 'болезненное влечение к алкоголю' (ОЖЕГОВ).
} 
находчивости переводчика романа Дж. Оруэлла, Nineteen Eighty-Four (1984 год), все же слово новояз относится к точным структурным лексическим калькам.

\section{Новояз}

- иноязычный прототип: анг. newspeak;

- семантическое соприкосновение лексемы-прототипа и лексемы-кальки явно представлено в словарных толкованиях слов:

- newspeak 'language that is not clear or honest, for example the language that is used in political propaganda' (OALD7); 'language used by politicians and government officials which is intentionally difficult to understand or which does not mean what it seems to mean and is therefore likely to confuse or deceive people' (Cam$b A L C)$;

○ новояз 'официальный или полуофициальный стиль письменной или устной речи, который обычно по идеологическим соображениям скрывает или маскирует внутреннее содержание' (ТСРЯ ХХ);

- структурное сходство

○ Прототип по своей словообразовательной структуре является словосложением с подчинительной связью компонентов, в форме:

new + speak: new 'нов(ый) ' + speak 'язык' (CAPC);

где new- 'used in compounds to describe sth that has recently happened' (OALD7) и -speak 'the language or jargon of a particular group, organization or subject: computerspeak, eurospeak' (OALD7);

- Словообразовательная характеристика заимствования: новояз: нов + о + яз.

Русское калькированное слово, как и его прототип, обосновано на подчинительном отношении двух корней: в качестве первого выступает основа качественного прилагательного: нов+ый - с конкретизирующей функцией (ср. новый язык); главным (опорным) компонентом предшествует интерфикс -о-. Новое слово новояз создается путем усечения корня существительного яз(blк), уточненного предшествующим компонентом в фигуре усеченной основы нов(bій), составляющих словосочетание новый язык. Осуществляя усечение корня оно противоречит правилам русского словообразования. ${ }^{10}$

Собственно лингвистических методов для раскрытия происхождения термина новояз все же недостаточно: последним и важнейшим аргументом является факт - знание автора, Дж. Оруэлла, создавшего в своем романе-антиутопии Nineteen Eighty-Four (1984 год) особый стиль

\footnotetext{
10 «Словосочетания, заменяемые сложными словами состоят из имени существительного и определяющего, подчиненного ему слова - прилагательного или другого существительного. При этом основное, опр еделяемое существительное входит в сложное слово целиком, составляя его последнюю, опорную часть» (Лопатин 1973, 41; графическое выделение Е. Ф.). В то же время данное новообразование соответствует правилам русской фонетики, согласно которым «сложные слова имеют одно главное ударение, преимущественно на опорном
} 
языка (или же речь), получивший название в английском языке newspeak и переведенное на русский язык как новояз. ${ }^{11}$

Большое количество точных структурных лексических калек представляют кальки с повторяющимся первым компонентом сложений. ${ }^{12}$

\section{2. Неточные кальки}

Неточные кальки представляют собой различного рода отступления в копировании как структуры, так и значения иноязычных слов-прототипов. В своей типологии Обара (1989: 60) представляет богатый набор подтипов неточных калек - это он делает на материале различных языков (см. выше). Ниже нами приводятся лишь подтипы, представленные примерами в русской лексике конца XX и начала XXI вв.

\subsection{1. Калька - словосочетание, прототип - словосложение}

Среди неточных структурных калек распространенный тип - кальки-словосочетания, прототипами которых в английском языке являются словосложения.

\section{банк данных}

- иноязычный прототип: анг. Databank;

- семантическое соприкосновение

- databank'a large amount of data on a particular subject that is stored in a computer' (OALD7);

○ банкданных 'совокупность данных, объединенных общностью применения, использования, но менее связанных между собой, чем в базе данных' $(T C P Я X X)$;

- структурное сходство

○ между компонентами подчинительная связь, в качестве управляемого слова выступает data / данных;

○ морфологическая корреспонденция самих корней с точки зрения категории числа: английскому существительному $\operatorname{data}^{13}$ в русском словосочетании соответствует лексема данные. В обоих языках форма множественного числа показывает, что данные берутся в некотором количестве, больше одного;

- структурная неточность

\footnotetext{
компоненте, как первоисточник, полуобернуться (ср. Филин 1979, 313), хотя в результате усечения корня ударение не на (правильном) первичном ударном слоге слова языц 11 Об особенностях новояза и об аналогичных структурах употребления термина новояз см. Земская 2004, 533-545.

${ }^{12} \mathrm{Cp}$. видеоигра < анг. videogame; видеолюбитель < анг. video fanatic; телесериал < анг. TV-Serial; телеконференция $<$ анг. teleconferencing, teleconference; квазиденьги < анг. quasi-money; поп-звезда < анг. pop star.

13 Английская лексема datum заимствование из латинского языка. Соблюдая оригинальную форму множественного числа она выступает в английском языке как data - для обозначения в информатике 'информаций, представленных в пригодном для компьютерной обработки виде' (ТCPЯ $X X)$. Сp. Также '(technical) a fact or piece of information' (OALD7).
} 
○ английский прототип - словосложение, а русская калька - словосочетание;

○ изменение последовательности компонентов в русском эквиваленте - в последствии перевода прототипа-словосложения притяжательной конструкцией;

○ лексема данные выступает в словоформе данных, т. е. в форме родительного падежа множественного числа, ее английский первообраз в именительном падеже множественного числа.

\subsection{2. Полукальки}

Кальки, получившие в терминологии Обары (и также в русской системе терминов) название «полукальки» возникают частично только путем перевода чужих первообразов. В следствие этого, словообразовательная прозрачность иноязычных словпрототипов размывается в процессе калькирования.

СД ${ }^{14}$-проигрыватель / компакт-диск-проигрыватель

- иноязычный прототип: анг. cd player;

- семантическое соприкосновение

- $c d$ player 'a machine that is used for playing music CDs' (CambALC);

- СД-проигрыватель / компакт-диск-проигрыватель 'проигрыватель для компакт-дисков' (ТСРЯ XX);

- структурное сходство

○ при тождестве выступающих корней;

○ прототип и калька по своей словообразовательной структуре являются словосложением с подчинительной связью компонентов, со значением 'проигрыватель для компакт-дисков' (ТСРЯ XX), в форме:

cd player: cd 'компакт-диск' + player' 3) 'проигрыватель; плеер' ( CAPC), a machine for reproducing sound or pictures that have been recorded on CDs, etc.: a CD / DVD / cassette / record player (OALD7);

○ СД-проигрыватель: СД 'компакт-диск' + проигрыватель 'аппарат для проигрывания пластинок с грамзаписью' (ОЖЕГОВ);

- структурная неточность

○ первый компонент русского словосложения не переведен, английская аббревиатура $C D$ выступает в транслитерации $C Д$, произношение которой однако осуществляется по правилам английского языка.

\section{4. Семантические кальки}

\footnotetext{
14 Произношение СД <сидй, ср. ТСРЯ ХХ. Английский прототип заимствован также фонетическим (не калькированным) способом в форме си-ди плейер.
} 
Собственно семантической калькой мы называем исконное слово, получающее новое значение под воздействием семантического слова-эквивалента в языке-доноре. Необходимой предпосылкой процесса собственного семантического калькирования является наличие точки семантического соприкосновения иноязычного слова и исконного, когда они обладают объединяющими их одинаковыми прямыми, номинативными значениями (ср. Шанский 1959, 201).

Заступающие ассоциационные кальки это исконные слова со сложной словообразовательной структурой, которые во втором значении являются эквивалентами иноязычных образцов с одним значением, как, например, польский глагол wygladać 'направлять взгляд (откуда-н. на что-н.)' получило второе значение под воздействием немецкого слова aussehen 'иметь тот или иной вид', в первом значении польского глагола в немецком языке употребительна глагольная форма с приставкой hinaus-, т.e. hinaussehen (см. Obara 1989, 61).

Принятие нового значения может основываться также на случайном фонетическом (или графическом) сходстве калькированного слова и его прототипа, который не обязательно должен быть многозначным словом. Именно таким путем обогатило свою семантику норвежское слово trøsta 'обрадовать' получая новое значение под воздействием английского to trust 'доверять, верить ' (см. Obara 1989, 61). Итак, основные типы семантических калек представляют:

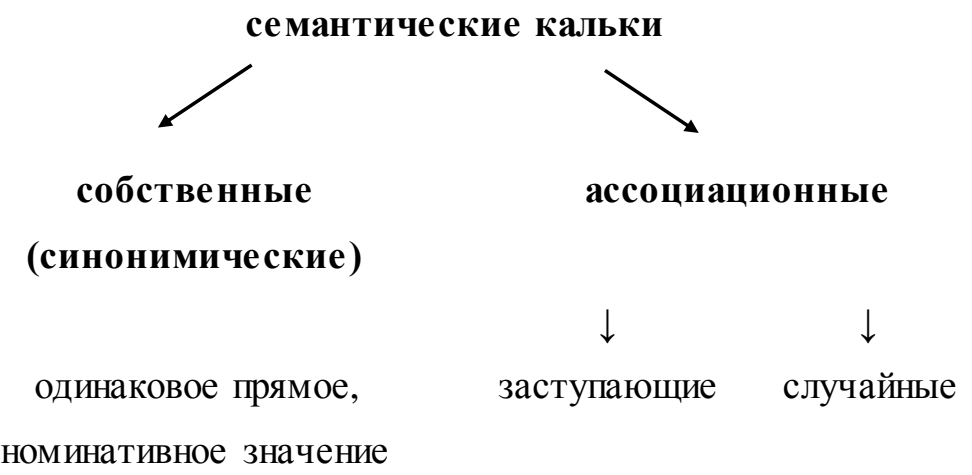

На основе семантического анализа лексем в языке-доноре и в языке-реципиенте мы полагаем, что следующие лексемы, уже с давних пор существующие в русском языке, получили новые, переносные значения, с большой вероятностью, от своих многозначных иностранных соответствий - английских прототипов накануне XXI столетия, и таким образом они являются собственными (синонимическими) семантическими кальками.

\begin{tabular}{|c|l|l|l|}
\hline \multicolumn{2}{|c|}{ Лексема } \\
\hline \multicolumn{2}{|c|}{ прототип в языке-доноре } & \multicolumn{1}{|c|}{ калька в языке-реципиенте } \\
\hline первичное значение & $\begin{array}{l}\text { вторичное, } \\
\text { переносное значение }\end{array}$ & первичное значение & $\begin{array}{l}\text { новое, приобретенное } \\
\text { под воздействием }\end{array}$ \\
\hline
\end{tabular}




\begin{tabular}{|c|c|c|c|}
\hline & & & $\begin{array}{l}\text { другого языка } \\
\text { значение }\end{array}$ \\
\hline \multicolumn{2}{|c|}{ bible } & \multicolumn{2}{|c|}{ библия } \\
\hline $\begin{array}{l}\text { 1) 'the holy book of the } \\
\text { Christian religion, consisting } \\
\text { of the Old Testament and } \\
\text { the New Testament' } \\
\text { 2) 'the holy book of the } \\
\text { Jewish religion, consisting } \\
\text { of the Torah (or Law), the } \\
\text { Prophets, and the Writings' } \\
\text { 3) 'a copy of the holy book } \\
\text { of the Christian or Jewish } \\
\text { religion' (OALD7) }\end{array}$ & $\begin{array}{l}\text { 'a book containing im- } \\
\text { portant information on a } \\
\text { subject, that y ou refer to } \\
\text { very often' }(O A L D 7)\end{array}$ & $\begin{array}{l}\text { 'Собрание священных } \\
\text { книг иудейской и } \\
\text { христианской религий' } \\
(O Ж Е Г О В)\end{array}$ & $\begin{array}{lr}\text { 'О книге, } & \text { излагающей } \\
\text { непр еложные } \\
\text { в какой-л. сфере духовной } \\
\text { или практической } \\
\text { деятельности. ' }(\text { ТСРЯ } X X)\end{array}$ \\
\hline \multicolumn{2}{|c|}{ virus } & \multicolumn{2}{|c|}{ вирус } \\
\hline $\begin{array}{l}\text { 1) 'living thing, too small to } \\
\text { be seen without a micro- } \\
\text { scope, that causes infectious } \\
\text { disease in people, animals } \\
\text { and plants' } \\
\text { 2) 'a disease caused by a } \\
\text { virus' } \\
(O A L D 7)\end{array}$ & $\begin{array}{l}\text { 'instructions that are hidden } \\
\text { within a computer program } \\
\text { and are designed to cause } \\
\text { faults or destroy data' } \\
(O A L D 7)\end{array}$ & $\begin{array}{l}\text { 'Мельчайшая неклеточная } \\
\text { частица, размножающаяся } \\
\text { в живых клетках, } \\
\text { возбудитель } \\
\text { инфекционного } \\
\text { заболевания.' } \\
(O Ж Е Г O В)\end{array}$ & $\begin{array}{l}\text { 'Специальная программа, } \\
\text { способная } \\
\text { самопроизвольно } \\
\text { присоединяться к другим } \\
\text { программам и при запуске } \\
\text { последних выполнять } \\
\text { различные нежелательные } \\
\text { действия: портить файлы, } \\
\text { стирать данные и т.п.' } \\
(T C P Я X X)\end{array}$ \\
\hline \multicolumn{2}{|c|}{ power } & \multicolumn{2}{|c|}{ держсава } \\
\hline $\begin{array}{l}\text { 'the phy sical ability to move } \\
\text { things, lift things, etc' } \\
(O A L D 7)\end{array}$ & $\begin{array}{l}\text { 1) 'power over people and } \\
\text { things- the ability to make } \\
\text { other people do what you } \\
\text { want' } \\
\text { 2) 'political power' } \\
\text { 3) 'a country with a lot of } \\
\text { influence in world affairs, or } \\
\text { with great military strength' } \\
(O A L D 7)\end{array}$ & $\begin{array}{l}\text { 1) См. государство. } \\
\text { 2) 'Золотой шар с короной } \\
\text { или крестом наверху - } \\
\text { эмблема власти, одна из } \\
\text { регалий } \\
(O Ж Е Г О В)\end{array}$ & 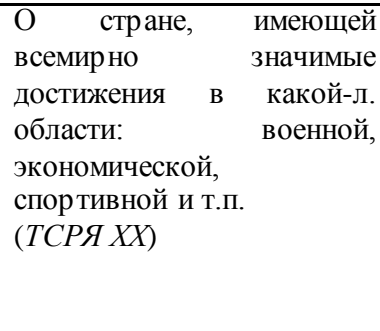 \\
\hline \multicolumn{2}{|c|}{ menu } & \multicolumn{2}{|c|}{ меню } \\
\hline $\begin{array}{l}\text { 'a list of the food that is } \\
\text { available at a restaurant or to } \\
\text { be served at a meal' } \\
(O A L D 7)\end{array}$ & $\begin{array}{l}\text { 'a list of possible choices } \\
\text { that are shown on a comput- } \\
\text { er screen' } \\
(\text { OALD7) }\end{array}$ & $\begin{array}{l}\text { 1) 'Подбор кушаний.' } \\
\text { 2) 'Листок с их перечнем } \\
\text { или информационного } \\
\text { содержания.' (ОЖЕГОВ) }\end{array}$ & $\begin{array}{l}\text { 'Список программ или } \\
\text { функций, } \\
\text { предоставляемых } \\
\text { пользователю компьютера } \\
\text { на выбор.' } \\
\text { (ТСРЯ XX) }\end{array}$ \\
\hline
\end{tabular}

\section{бритоголовые}

Особенно занимательным является семантическое развитие лексемы бритоголовые, являющейся в отличии от всех остальных, мотивированным словом. Оно наличествует в русском языке как бритоголовый 'с обритой головой' (СРЯ). В последнее время оно стало употребляться в языке в значении 'молодежная группировка (обычно националистического толка), протестующая своим внешним видом против общепринятых норм поведения (в противопоставление длинноволосым, битлсам и т.п.)' (ТСРЯ $X X)$ - под воздействием английского слова skinhead(s). Само слово в своем звучании, материальном составе и словообразовательной структуре выглядит исконным, в данном случае калькируется семантика 
чужого слова. Особенностью данного семантического калькирования является тип слова, получающего новое значение. Семантическая деривация слов проявляется обычно в непроизводных словах, как в выше перечисленных примерах.

- иноязычный прототип: анг. skinhead(s);

- семантическое соприкосновение

- $\operatorname{skinhead}(s)$

1) 'a hairstyle in which the hair is so short that the skin on the head can be seen';

2) A. 'a young person, especially a man, who has very short hair or no hair and is part of a group, often a violent group' (CambALC);

Б. 'a young person, usually a man, with a shaved head and often wearing braces and heavy boots, especially Doc Martens. Skinheads first appeared in Britain in the 1960s and are known for their violent behaviour and their support for right-wing political groups such as the British National Party. ' (OALD7);

- бритоголовый

1) 'с обритой головой' (СРЯ);

2) 'молодежная группировка (обычно националистического толка), протестующая своим внешним видом против общепринятых норм поведения (в противопоставление длинноволосым, битлсам и т.п.)' (ТСРЯ $X X)$.

Словообразовательная характеристика кальки-лексемы - существительного адъективного склонения:

- слово является результатом суффиксально-сложного способа словообразования,

- оно содержит две основы;

- в качестве первой основы используется основа страдательного причастия прошедшего времени, образованного от глагола брить: брит+ый;

- основы соединены с помощью интерфикса -о-;

- в составе опорного компонента - нового по структуре суффиксальной части содержится имя существительное, ср. напр., большеголовый, двухголовый, длинноголовый, дубинноголовый;

- словообразовательная структура слова: брит $+o+$ голов + ble.

Словообразовательная структура слова-прототипа: skin-head 'кожа-голова', т.е. оно является сложным словом. Точное структурное калькирование дало бы в результате поморфемный перевод: *коженноголовый.

Лексема бритоголовый уже давним давно образовалось в русской лексике со значением 'c обритой головой', к этому конкретному значению добавился новый компонент. Слово получило новое, переносное значение под влиянием иностранного слова. Необходимой предпосылкой процесса калькирования явилось наличие точки семантического 
соприкосновения чужого слова и исконного: 'побрившийся наголо'. Данное понятие, параллельно с калькой, вошло в русский язык постсоветского времени тоже как фонетическое заимствование скинхэды / скинхеды - сохранив свою морфологическую особенность: употребление прежде всего формы множественного числа.

Перечень примеров семантического калькирования в русском языке конца XX начала XXI вв. бесконечен, здесь мы перечисляем лишь некоторые кальки-неосемантизмы из области информатики: окно, пароль, периферия, считать.

\section{5. Фразеологические кальки}

Термином «фразеологические кальки» определяются фразеологизмы являющиеся переводами иноязычных образцов, чаще всего словосочетаний, обладающих свойством идиоматичности. На основе степени точности перевода и качества отступлений от прототипов Обара предлагает следующую классификацию фразеологических калек (Obara 1989, 74):

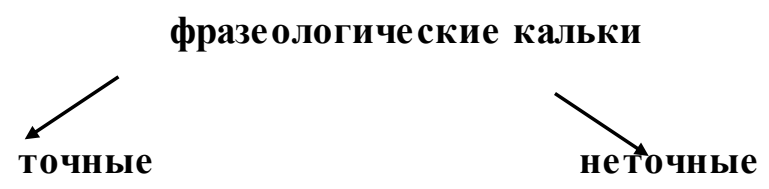

верно копирующие лексику, с лексическими отступлениями грамматику и семантику прототипов

$$
\begin{aligned}
& \text { с грамматическими отступлениями } \\
& \text { с семантическими отступлениями } \\
& \text { частичный только перевод чужих } \\
& \text { первообразов (фразеологические } \\
& \text { полукальки) }
\end{aligned}
$$

\section{1. Точные фразеологические кальки}

При точном калькировании идиомы с фразеологически связанными значениями соответствуют семантике фразеологизма-первообраза, члены-компоненты (их качество, количество и последовательность) тоже верно копируют прототип в форме устойчивого словосочетания, ср.:

\section{отмыть/отмывать деньги}

- иноязычный прототип: анг. to launder money;

- семантическое соприкосновение 
- to launder money 'to move money that has been obtained illegally into foreign bank accounts or legal businesses so that it is difficult for people to know where the money came from' $(O A L D)$;

○ отмыть/отмывать (грязные) деньги 'легализация незаконно полученных доходов, путем инвестирования их в промышленность, отчисления на благотворные цели и т. п.' (ТСРЯ $X X)$.

\section{2. Неточные фразеологические кальки}

\subsection{1. Синтаксическое отступление}

Грамматическое отступление, точнее синтаксическое отступление выступает во многих фразеологических кальках: определительные обороты английского языка переводятся притяжательными конструкциями в русском языке:

\section{школа бизнеса}

- иноязычный прототип: анг. business school;

- семантическое соприкосновение

- business school 'a part of a college or university that teaches business, often to graduates (= people who already have a first degree)' $(O A L D)$;

○ школа бизнеса 'центр по обучению частных лиц основам предпринимательства, коммерческой деятельности: маркетингу, бухгалтерскому учету и т. п.' (ТСРЯ ХX);

- структурное расхождение

русский идиом представляет ту же самую семантику, как его первообраз, однако в нем порядок следования лексем, в согласии с правилами принимающего языка, не совпадает с порядком следования воспроизводимых им лексических единиц в калькируемом объекте.

\subsection{2. Морфологическое отступление}

Кроме синтаксического отступления наблюдается также морфологическое отодвигание в употреблении множественного числа вместо первичного единственного в фразеологизмепереводе:

\section{утечка мозгов}

- иноязычный прототип: анг. brain drain;

- семантическое соприкосновение

- brain drain 'the movement of highly skilled and qualified people to a country where they can work in better conditions and earn more money' (OALD); 
○ утечка мозгов 'отъезд ученых за пределы страны в силу экономических, политических и т.п. причин' (ТСРЯ $X X)$.

\subsection{3. Лексическое отступление}

Лексические отступления возникли при переводе первообразов в таких устойчивых словосочетаниях, как

\section{всемирная паутина}

- иноязычный прототип: анг. World wide web;

- семантическое соприкосновение

- World wide web 'the system of connected documents on the Internet, which often contain colour pictures, video and sound, and can be searched for information about a particular subject' (CambALC);

○ всемирная паутина 'сервис в интернете, представляющий все тексты, находящиеся в этой сети, как связанные друг с другом системой ссылок' (ТСРЯ $X X)$;

- структурное расхождение

○ World wide 'мировой ширины' переведено на русский язык сложным прилагательным всемирный,ср.

○ World wide web: World 'мир, свет, Вселенная' + wide 'широкий' + web 'ткань; паутина, сплетение'

- всемирная паутина: всемирный + паутина

\section{6. Заключение}

Те конкретные случаи калькирования, которые приводятся выше в тексте, были выбраны для иллюстрации активных на рубеже XX и XXI веков процессов калькирования. Однако, как мы видели, тема требует более глубокого исследования: предлагаемая Й. Обарой универсальная классификация калек нуждается, с одной стороны, в уточнении для применения ее на русской почве, с другой стороны, и в привлечении в исследование иных источников, ведь в анализируемом автором данной работы материале не представлены все теоретически возможные подтипы калек.

Углубленное и детальное изучение калькирования, кроме исследования более или менее легко обнаруживаемых изменений в лексике, а также разных форм скрытого влияния других языков, не только в лексике, но и, в грамматической системе, поможет в изучении комплексных проблем языковых контактов. В прикладном аспекте многостороннее описание калек играет важную роль во всех основных путях преодоления языкового барьера (обучение языкам, все виды перевода [включая машинный], итп.). 



\section{Литература}

Н. С. Арапова, Кальки в русском языке послепетровского периода. Опыт словаря. Москва 2000.

A. А. Зализняк, Семантическая деривация в синхронии: Проект "Каталога семантических переходов": Вопросы языкознания 2 (Москва 2001) 13-25.

E. А. Земская, Язык как деятельность: Морфема. Слово. Речь. Москва 2004 (Studia philologica).

Л. П.: Крысин, Иноязычное слово в контексте современной общественной жизни: Е. А. Земская (отв. ред.), Русский язык конца ХХ столетия (1985-1995). Москва 2000, 142-161.

Л. П. Крысин, Лексическое заимствование и калькирование в руссом языке последних десятилетий: Вопросы языкознания 6 (Москва 2002) 27-34.

B. В. Лопатин, Рождение слова. Неологизмы и окказиональные образования. Москва 1973 (Академия наук СССР: Научно-популярная серия).

Ф. П. Филин (отв. ред.), История лексики русского литературного языка конца XVII - начала XIX века. Москва 1979.

М. И. Фомина, Современный русский язык. Лексикология. 2-е изд., испр. и доп. Москва 1983.

Н. М. Шанский, Очерки по русскому словообразованию и лексикологии. Москва 1959.

KISS Lajos, Szláv tükörszók és tükörjelentések a magyarban. [Славянские лексические и семантические кальки в венгерском языке] Budapest 1976 (Nyelvtudományi Értekezések 92.).

Jerzy OBARA, Teoretyczne problemy kalkowania. Wrocław 1989 (Acta Universitatis Wratislaviensis, 1040).

May Sмітн, The Influence of French on Eighteenth-Century Literary Russian. Semantic and Phraseological Calques. Bern/Frankfurt a.M./New York 2006.

Teresa SмÓŁKOWA (red.), Nowe słownictwo polskie. Materiały z prasy lat 1985-1992, 1-2. Kraków 1998 (Prace Instytutu Języka Polskiego, 108).

Krystyna WASZAKOWA: Rozkładalność i kompozycjalność struktur słowotwórczych: Kleszczowa, Krystyna - Selimski, Ludwig (red.): Słowotwórstwo a inne sposoby nominacji. Materiały z 4 konferencji Komisji Słowotwórstwa przy Międzynarodowym Komitecie Slawistów. Katowice 27-29 września 2000 r. Katowice 2000, 63-69.

ОЖЕГОв - С. И. ОЖЕГОВ, Словар ь русского языка. Около 57000 слов. Под ред. Чл.-корр. АН СССР Н. Ю. Шведовой. 18-е изд., стереотип. Москва 1987.

САРС-Л. П. ПоПОВА - Н. Р. МокИНА - Г. В. ЗАХАРОВА: Современный англо-русский словарь. Электронные словари для системы Контекст 6.0. Москва 2004.

СРЯ - Словарь русского языка в четырех томах, 1-4. 2-е исправленное и дополненное издание. Гл. ред. второго издания А.П. Евгеньева. Москва 1983.

BSE - A. BAŃKOW SKI, Etymologiczny słownik języ ka polskiego. Warszawa 2000.

OALD7 - Oxford Advanced Learner's Dictionary of Current English. A S Hornby. $7^{\text {th }}$ edition. Oxford 2005.

OALD7 - Oxford Advanced Learner's Compass. Oxford 2005. CD-ROM.

CambALC - Cambridge Advanced Learner's Compass. Cambridge 2003. CD-ROM.

ТСРЯ ХХ - Толковый словарь русского языка конца XX века. Языковые изменения. Под ред. Г. Н. Скляревской. СПб. 1998.

ТССРЯ XX - Толковый словарь современного русского языка. Языковые изменения конца ХХ века. Под ред. Г. Н. Скляревской. Москва 2001. 